\title{
PENGARUH MODEL PEMBELAJARAN RESOLUSI KONFLIK TERHADAP HASIL BELAJAR SISWA PADA MATERI FISIKA
}

\author{
Mega Ilyasa Wisic ${ }^{1}$, Nana $^{2}$ \\ Universitas Siliwangi Tasikmalaya, \\ Jawa Barat, Indonesia \\ Email: megailyasaw12@gmail.com
}

\begin{abstract}
ABSTRAK: Tujuan penulisan ini untuk mendeskripsikan pengaruh model pembelajaran resolusi konflik terhadap hasil belajar siswa pada materi fisika. Penulisan ini dilatarbelakangi oleh masih kurangnya pemahaman siswa terhadap materi pembelajaran fisika. Untuk itu perlu ada upaya yang dapat mengatasi permasalah tersebut dengan menerapkan model pembelajaran resolusi konflik. Model resolusi konflik merupakan kemampuan dan keterampilan siswa dalam menyikapi dan memecahkan serta mengambil tindakan terhadap berbagai fenomena dan masalah-masalah social budaya yang terjadi di lingkungan masyarakatnya (lokal, regional, nasional, dan internasional) dengan bersandar pada nilai-nilai dan budaya masyarakat dimana mereka hidup dan berkembang. Metode yang digunakan dalam penulisan ini yaitu studi kepustakaan dengan mengkaji beberapa literature untuk dianalisis dan dibuat kesimpulan. Hasil penulisan ini menunjukkan bahwa pengaruh model pembelajaran resolusi konflik pada materi fisika dapat menjadi solusi dari permasalahan yang ditemui dalam proses belajar mengajar terutama terhadap hasil belajar siswa. Kata Kunci: Model Pembelajaran Resolusi Konflik, Materi Fisika, Hasil Belajar Siswa.
\end{abstract}

\section{PENDAhUluan}

Ilmu Pengetahuan Alam (IPA) merupakan salah satu ilmu yang mempelajari mengenai seluruh alam semesta dan juga isinya. Tetapi IPA mempunyai suatu batasan pengetahuan yaitu mengenai hal-hal yang dapat hanya dipahami oleh panca indera (pendengaran, pengecapan, penglihatan, sentuhan dan rabaan). Hal ini juga dapat dikatakan bahwa IPA atau fisika yaitu suatu ilmu yang dapat diperoleh melalui pembuktian dan pembelajaran. Menurut Izaak (2010), pembelajaran IPA tidak hanya terbatas mengenai belajar hukum, konsep, prinsip, fakta saja, tetapi pembelajaran IPA juga belajar mengenai cara memperoleh informasi, bekerja secara ilmiah, penerapan teknologi, dan juga kemampuan berpikir. Tujuan dari pembelajaran IPA tersebut yaitu untuk dapat meningkatkan kompotensi yang diperlukan oleh siswa atau peserta didik untuk dapat memenuhi kebutuhan dari berbagai situasi dan juga diarahkan untuk mengembangkan suatu kemampuan berpikir (Toharnudin dkk, 2017).

Fisika adalah salah satu cabang dari Ilmu Pengetahuan Alam (IPA) yang mempelajari tentang benda-benda yang berada di alam semesta secara fisik dan juga dapat dituliskan secara matematis agar dapat dipahami oleh manusia dan dapat dimanfaatkan untuk kesejahteraan umat manusia (Sujanem dkk, 2012). Berdasarkan pernyataan tersebut maka pembelajaran fisika tidak dapat lepas dari penguasaan konsep, bekerja secara ilmiah, dan menerapkannya dalam suatu penyelesaian masalah. Akan tetapi, pembelajaran fisika pada sekarang ini cenderung hanya menekankan pada penguasaan konsep dan mengesampingkan kemampuan dalam pemecahan masalah mengenai fisika, sehingga siswa tidak mempunyai kemampuan untuk memecahkan suatu permasalahan atau dapat disebut kemampuan siswa dalam memecahkan suatu permasalahan masih tergolong sangat rendah (Hudha dkk, 2017). 
Suatu pembelajaran tidak hanya mempelajari konsep, teori dan fakta tetapi juga aplikasinya dalam kehidupan seharihari. Materi pembelajaran tidak hanya tersusun atas hal-hal sederhana yang bersifat hafalan dan pemahaman, tetapi juga tersusun atas materi yang kompleks yang memerlukan analisis, aplikasi dan sistesis (Trianto, 2007).

Rendahnya hasil belajar peserta didik dapat diakibatkan oleh cara mengajar guru yang masih berpusat pada guru. Semua materi yang diajarkan atau dijelaskan oleh guru, peserta didik hanya menjadi pendengar dan pencatat yang baik. Pembelajaran seperti ini dikenal dengan model pembelajaran konvensional. Pembelajaran konvensional merupakan pembelajaran yang menekankan pada metode ceramah yang dapat menyebabkan kurangnya kemampuan peserta didik dalam mengeksplorasi materi pembelajaran secara mandiri.

Terkait dengan itu, maka cara yang dapat dilakukan oleh guru adalah memilih model pembelajaran resolusi konflik. Model pembelajaran resolusi konflik dipandang mampu memberikan pemahaman terhadap suatu masalah dan mampu melatih siswa dalam menyelesaikan permasalahan. Selain itu, model pembelajaran ini menawarkan sejumlah solusi kepada guru untuk menjadikan pembelajaran itu menarik. Dengan demikian model resolusi konflik merupakan suatu model pembelajaran yang dipandang relevan untuk dikembangkan dalam merealisasikan tujuan pembelajaran.

Menurut Lasmawan (2012) Model resolusi konflik ialah kemampuan dan keterampilan siswa dalam menyikapi dan memecahkan serta mengambil tindakan terhadap berbagai fenomena dan masalah-masalah social budaya yang terjadi di lingkungan masyarakatnya (lokal, regional, nasional, dan internasional) dengan bersandar pada nilai-nilai dan budaya masyarakat dimana mereka hidup dan berkembang. Dalam pembelajaran resolusi konflik, belajar dan membelajarkan merupakan dua sisi yang saling melengkapi satu sama lainnya. Artinya dalam proses belajar mengajar, guru dapat membelajarkan siswa dan siswa itu sendiri juga dapat belajar dan sekaligus membelajarkan diri dengan siswa yang lainnya. Dengan pola pembelajaran seperti ini, maka pusat pembelajaran bukan lagi pada guru, melainkan pada siswa itu sendiri.

Montgomery (dalam Lasmawan, 2012) menyatakan bahwa model reosolusi konflik merupakan suatu model pembelajaran yang didasari pada suatu pandangan bahwa ada hubungan kausalitas antara fenomena social, budaya, dan kemampuan serta tanggung jawab social individu bagi kehidupan masyarakat secara siklus yang pada akhirnya membuat kehidupan masyarakat secara siklus yang pada akhirnya membuat kehidupan masyarakat secara siklus yang pada akhirnya membuat kehidupan manusia lebih baik dan mapan. Selain itu, Lasmawan (2012) juga menyatakan bahwa Model resolusi konflik (MRK) adalah kemampuan dan keterampilan siswa dalam menyikapi dan memecahkan serta mengambil tindakan terhadap berbagai fenomena dan masalah-masalah social budaya yang terjadi di lingkungan masyarakatnya (lokal, regional, nasional, dan internasional) dengan bersandar pada nilainilai sosial dan budaya masyarakat dimana mereka hidup dan berkembang.

Hasil belajar merupakan tingkat keberhasilan siswa setelah melalu pengalaman melalui pembelajaran yang dilakukan siswa. Menurut Suprihatiningrum (2012) hasil belajar sangat erat kaitannya dengan belajar atau poses belajar. Hasil belajar pada sasarannya dikelompokkan dalam dua kelompok, yaitu pengetahuan dan keterampilan. Pengetahuan dibedakan menjadi empat macam, yaitu pengetahuan tentang fakta - fakta, pengetahuan tentang prosedur, pengetahuan konsep, dan keterampilan untuk berinteraksi. Sedangkan pengertian hasil belajar menurut Bloom, et al. dalam Kurniawan (2014) dibagimenjadi tiga bagian yaitu kognitif, afektif, dan psikomotor. 
Hasil belajar dapat didefinisikan sebagai salah satu faktor yang dapat menentukan suatu proses pembelajaran. Kriteria dalam menentukan suatu keberhasilan belajar siswa diukur dari seberapa banyak materi pembelajaran yang dapat dikuasai oleh siswa, berbeda dengan proses pembelajaran yang dilakukan dengan kriteria keberhasilan yang ditentukan oleh sejauh mana siswa dapat memanfaatkan potensi otak siswa itu sendiri untuk memecahkan suatu persoalan atau permasalahan (Sanjaya, 2011). Menurut Dimyati dan Mudjiono (2001), menyatakan bahwa "hasil belajar adalah hasil dari suatu interaksi atau tindakan belajar mengajar. Dari sisi guru atau pengajar tindakan mengajar diakhiri dengan suatu proses yaitu mengenai evaluasi hasil belajar. Sedangkan dari sisi siswa, hasil belajar dapat diartikan sebagai proses berakhirnya penggal dan puncak proses pembelajaran tersebut".

Guru atau pengajar harus dapat menggunakan suatu proses pembelajaran yang dapat menggerakan peserta didik atau siswa menuju kemandirian, belajar sepanjang hayat, dan juga kehidupan yang lebih luas lagi. Lingkungan belajar yang dibangun guru tersebut harus mendorong cara berpikir kritis peserta didiknya sehingga peserta didik tersebut dapat dengan mudah untuk memahami suatu materi pembelajaran yaitu salah satunya materi fisika mengenai materi dinamika rotasi, dan juga dapat meningkatkan hasil belajar siswa yaitu dengan menerapkan atau menggunakan suatu model pembelajaran.

Berdasarkan uraian di atas, maka dipandang perlu untuk mengembangkan sebuah model pembelajaran yaitu salah satunya model pembelajaran Resolusi Konflik untuk meningkatkan hasil belajar peserta didik pada materi Fisika.

\section{METODE PENELITIAN}

Metode yang digunakan dalam penulisan ini berupa studi kepustakaan. Data dikumpulkan untuk dianalisis kemudian disajikan dalam hasil dan pembahasan agar dapat dibuat kesimpulan.

\section{HASIL DAN PEMBAHASAN}

Penguasaan konsep dapat menunjukan siswa menguasai materi-matei dengan baik atau tidak, sehingga penting bagi calon guru mengetahui kesulitan siswa tentang berbagai konsep fisika dalam menentukan strategi belajar yang baik, untuk mengurangi atau menghilangkan kesulitan pada materi tersebut (Apriani \& Murniati, 2016).

\section{Model Pembelajaran Resolusi Konflik}

Menurut Lasmawan (2012) Model resolusi konflik ialah kemampuan dan keterampilan siswa dalam menyikapi dan memecahkan serta mengambil tindakan terhadap berbagai fenomena dan masalah-masalah social budaya yang terjadi di lingkungan masyarakatnya (lokal, regional, nasional, dan internasional) dengan bersandar pada nilai-nilai dan budaya masyarakat dimana mereka hidup dan berkembang. Dalam pembelajaran resolusi konflik, belajar dan membelajarkan merupakan dua sisi yang saling melengkapi satu sama lainnya. Artinya dalam proses belajar mengajar, guru dapat membelajarkan siswa dan siswa itu sendiri juga dapat belajar dan sekaligus membelajarkan diri dengan siswa yang lainnya. Dengan pola pembelajaran seperti ini, maka pusat pembelajaran bukan lagi pada guru, melainkan pada siswa itu sendiri.

Montgomery (dalam Lasmawan, 2012) menyatakan bahwa model reosolusi konflik merupakan suatu model pembelajaran yang didasari pada suatu pandangan bahwa ada hubungan kausalitas antara fenomena social, budaya, dan kemampuan serta tanggung jawab 
social individu bagi kehidupan masyarakat secara siklus yang pada akhirnya membuat kehidupan masyarakat secara siklus yang pada akhirnya membuat kehidupan masyarakat secara siklus yang pada akhirnya membuat kehidupan manusia lebih baik dan mapan. Selain itu, Lasmawan (2012) juga menyatakan bahwa Model resolusi konflik (MRK) adalah kemampuan dan keterampilan siswa dalam menyikapi dan memecahkan serta mengambil tindakan terhadap berbagai fenomena dan masalah-masalah social budaya yang terjadi di lingkungan masyarakatnya (lokal, regional, nasional, dan internasional) dengan bersandar pada nilainilai sosial dan budaya masyarakat dimana mereka hidup dan berkembang.

\section{Hasil Belajar Siswa}

Hasil belajar merupakan tingkat keberhasilan siswa setelah melalu pengalaman melalui pembelajaran yang dilakukan siswa. Menurut Suprihatiningrum (2012) hasil belajar sangat erat kaitannya dengan belajar atau poses belajar. Hasil belajar pada sasarannya dikelompokkan dalam dua kelompok, yaitu pengetahuan dan keterampilan. Pengetahuan dibedakan menjadi empat macam, yaitu pengetahuan tentang fakta - fakta, pengetahuan tentang prosedur, pengetahuan konsep, dan keterampilan untuk berinteraksi. Sedangkan pengertian hasil belajar menurut Bloom, et al. dalam Kurniawan (2014) dibagimenjadi tiga bagian yaitu kognitif, afektif, dan psikomotor.

Hasil belajar dapat didefinisikan sebagai salah satu faktor yang dapat menentukan suatu proses pembelajaran. Kriteria dalam menentukan suatu keberhasilan belajar siswa diukur dari seberapa banyak materi pembelajaran yang dapat dikuasai oleh siswa, berbeda dengan proses pembelajaran yang dilakukan dengan kriteria keberhasilan yang ditentukan oleh sejauh mana siswa dapat memanfaatkan potensi otak siswa itu sendiri untuk memecahkan suatu persoalan atau permasalahan (Sanjaya, 2011). Menurut Dimyati dan Mudjiono (2001), menyatakan bahwa "hasil belajar adalah hasil dari suatu interaksi atau tindakan belajar mengajar. Dari sisi guru atau pengajar tindakan mengajar diakhiri dengan suatu proses yaitu mengenai evaluasi hasil belajar. Sedangkan dari sisi siswa, hasil belajar dapat diartikan sebagai proses berakhirnya penggal dan puncak proses pembelajaran tersebut".

Menurut Gagne \& Briggs (dalam Suprihatiningrum, 2016) hasil belajar merupakan suatu kemampuan yang dipunyai oleh siswa atau peserta didik sebagai akibat dari perbuatan proses belajar dan juga dapat diamati dengan cara penampilan siswa atau peserta didik. Hasil belajar erat kaitannya dengan kegiatan belajar serta proses pembelajaran. Hasil belakar akan dicapai secara maksimal pada saat kegiatan belajar dan proses pembelajaran berjalan dengan baik. Siswa juga sudah dapat dikatakan mencapai hasil belajar pada saat siswa tersebut telah mengalami perubahan perilaku dengan cara melalui proses pembelajaran. Perubahan perilaku dapat diperoleh oleh siswa atau peserta didik ketika siswa tersebut sudah meyelesaikan suatu kegiatan proses pembelajaran melalui interaksi dengan berbagai macam sumber belajar dan lingkungan belajarnya.

\section{Pengaruh Model Pembelajaran Resolusi Konflik Terhadap Hasil Belajar Peserta Didik pada Materi Fisika}

Menurut Lasmawan (2012) Model resolusi konflik ialah kemampuan dan keterampilan siswa dalam menyikapi dan memecahkan serta mengambil tindakan terhadap berbagai fenomena dan masalah-masalah social budaya yang terjadi di lingkungan masyarakatnya (lokal, regional, nasional, dan internasional) dengan bersandar pada nilai-nilai dan budaya masyarakat dimana mereka hidup dan berkembang. Dalam pembelajaran resolusi konflik, 
belajar dan membelajarkan merupakan dua sisi yang saling melengkapi satu sama lainnya. Artinya dalam proses belajar mengajar, guru dapat membelajarkan siswa dan siswa itu sendiri juga dapat belajar dan sekaligus membelajarkan diri dengan siswa yang lainnya. Dengan pola pembelajaran seperti ini, maka pusat pembelajaran bukan lagi pada guru, melainkan pada siswa itu sendiri.

Model pembelajaran resolusi konflik ini dapat menjadikan siswa sebagai subjek di dalam pembelajaran. Siswa dapat aktif dalam menemukan suatu konsep melalui pengamatan atau eksperimen secara langsung, bukan sekedar dari menghafal buku materi maupun penejelasan dari guru. Model pembelajaran ini memungkinkan siswa aktif dalam proses pembelajaran, memberikan kesempatan kepada siswa untuk mengkontruksi pengetahuannya, mengkomunikasikan pemikirannya dan menuliskan hasil diskusinya sehingga siswa lebih menguasai dan memahami dan juga mampu menjadikan siswa lebih berpikir kritis pada materi pembelajaran.

\section{PENUTUP}

Berdasarkan hasil analisis dapat disimpulkan bahwa model pembelajaran resolusi konflik ini dapat berpengaruh terhadap hasil belajar siswa pada materi fisika.

\section{UCAPAN TERIMAKASIH}

Terima kasih kepada semua pihak yang telah membantu demi kesempurnaan artikel ini menjadi lebih baik.

\section{DAFTAR PUSTAKA}

Apriani, Hesti, dkk. (2016). Pengembangan Handout Dinamika Rotasi dan Kesetimbangan Benda Tegar Berbasis Kontekstual Kelas XI IPA SMA. Jurnal Inovasi dan Pembelajaran Fisika. 3(2).

Dimyati dan Mudjiono. 2010. Belajar dan Pembelajaran. Jakarta: Rineka Cipta.

Hudha, M.N., Aji, S.D., Permatasari, A., Purnama, R.D. (2017). aPBL (authenthic Problem Based Learning) untuk Meningkatkan Kemampuan Berpikir Siswa. Jurnal Pendidikan Matematika dan IPA, 8(1). 64-70

Izaak H. W. (2010). Pengembangan Model Modul IPA Berbasis Problem Solving Method Berdasarkan Karakteristik Siswa dalam Pembelajaran Di Smp/Mts. Cakrawala Pendidikan, Juni 2010, Th. XXIX, no. 2. Ambon: FKIP Pattimura.

Kurniawan, D. 2014. Pembelajaran TEMATIK (Teori, Praktik, dan Penilaian). Bandung : Alfabeta.

Lasmawan, W. 2012. Pembelajaran Inovatif Dalam pendidikan IPS, (makalah) disampakan pada seminar pendidikan dan pelatihan profesi guru (PLPG) Singaraja. UNDIKSHA

Sanjaya, Wina. 2011. Penelitian Tindakan Kelas. Jakarta: Kencana Prenada Media Group. 
Sujanem, R., Suwindra, I.N.P., \& Tika, I.K. (2012). Pengembangan Modul Fisika Kontekstual Interaktif Berbasis Web Untuk Siswa Kelas I SMA. Jurnal Pendidikan dan Pengajaran, 42(2): 97-104.

Suprihatiningrum, J. 2014. Strategi Pembelajaran. Yogyakarta : AR-RUZZ MEDIA.

Suprihatiningrum, Jamil. (2016). Strategi Pembelajaran Teori \& Aplikasi. Yogyakarta: Ar-Ruzz Media.

Toharudin, U., Hendrawati, S., \& Rustaman, A. (2011). Membangun Literasi Sains Peserta Didik. Bandung : Pendidikan. 